\title{
The Russian Federation as a subject of defamatory civil law relations during the formation of the digital economy
}

\author{
Alexey Telnov* \\ Peoples' Friendship University of Russia (RUDN University), 117198 Moscow, Russia
}

\begin{abstract}
The subject of the study of this article is public relations associated with the dissemination of untrue, defamatory information (defamation) with respect to the Russian state, concerning various spheres of its activities, as well as the relevant norms of Russian civil law, the norms of international law governing non-material goods, personal non-property rights of the Russian Federation, as an independent participant of civil legal relations, the provisions of the legal doctrine and judicial practice concerning the relevant objects of civil rights (reputation, business reputation).
\end{abstract}

\section{Introduction}

During the rapid development of the digital economy and the rapid development of information technologies, as part of the ongoing formation of a digital society, there has been a sharp and avalanche-like increase in the flow of information directly related to the rights and obligations of all subjects of civil and other public relations and, above all, those relations to which the Russian Federation is a party, which has led to an acute need for scientific understanding of the impact of digitalization on these relations.

In this regard, the new processes of digitalization and the expansion of access to information for everyone, including those obtained from electronic media, have led to the emergence of new risks, challenges and threats to information security of the state.

Such challenges and threats undoubtedly include the recent increase in the frequency of large flows of information, fake news, and publications discrediting the Russian Federation in various parts of the information space. In recent years, streams of lies have simply flooded the entire information space. It has acquired the character of an information "cold" war against the Russian Federation, aimed at destroying the impeccable reputation of the Russian Federation in all spheres of its activity. There are many such examples of defamation: the contribution of our country to the victory in World War II is vilified, the cultural, moral, economic, and general social potential of the country is deliberately distorted and belittled, Russia's sporting achievements are questioned, etc., etc. As a result, a distorted view of many spheres of activity of the Russian Federation is artificially formed in the minds of many citizens and the entire society when there is no real reason for it

* Corresponding author: at82@mail.ru 
In this regard, the protection of the information space from fake news and publications, defamation, and other negative phenomena and processes is now a strategic and key task in the field of ensuring the national interests of the Russian Federation in the context of the development of the digital economy. This, in turn, requires the improvement of existing and the formation of new mechanisms of legal regulation of social relations, as well as the introduction of unambiguous legal responsibility in the event of violations in the information sphere, in which information flows play a crucial economic, social and cultural role, which is not unimportant in the digital society. As noted, "Disinformation is a public issue that draws attention to the proliferation of content on digital networks, its relationship to the protection of the democratic system and the detrimental effects it has on the rights of citizens. This is not a new problem, but networks are now being used to spread hoaxes that suit different interests, but always to undermine trust in public institutions and, ultimately, in the established social order" [1].

The purpose of this study is to substantiate the feasibility of introducing into law such concepts as "reputation" and "defamation" concerning the Russian Federation, as a subject of civil law relations, based on repeated situations involving the dissemination of defamatory information (defamation) in relation to it, as well as ensuring that, given the rapid development of digitalization and digital technology, Russia can protect this special type of intangible good as "reputation".

\section{Methods}

The methodological basis of the study consists of general scientific and special methods, in particular, theoretical, comparative-legal, method of analysis, and synthesis.

\section{Results and discussion}

In the case of defamation (dissemination of defamatory information that does not correspond to reality), a civil legal relationship should arise between the participants in social relations to protect the intangible good belonging to the person regarding whom the defamation took place. Such a legal relationship arises when the aggrieved person, the victim, wishes to exercise his or her subjective right to restore his or her position before the defamation.

Participants of the mentioned legal relations become carriers of civil rights and obligations, and, as G.F. Shershenevich pointed out: "One person to whom a right belongs is called an active subject, otherwise a subject of law; another person on whom a corresponding obligation lies is called a passive subject" [2]. In this context, the active subject, or the entity with the right, is the aggrieved person who has suffered the harm caused by the defamation and who has the right to claim compensation for the harm suffered and restore his position before the harm. Accordingly, the passive subject bearing the due responsibility would be the person who committed the defamation and whose wrongful conduct resulted in the harm.

Clauses 2 and 4 of the Resolution of the Plenum of the Supreme Court of the Russian Federation dated February 24, 2005, No. 3 "On judicial practice in cases concerning the protection of honor and dignity of citizens as well as the business reputation of legal entities" specifies the active subjects who have the right to file defamation lawsuits - citizens and legal entities who believe that defamatory information about them has been distributed that is not true. Clause 5 of the above Resolution of the Plenum outlines the possible passive subjects to be liable - the authors of untrue, defamatory information, the persons who disseminated this information, the author and the editorial board of the media, including electronic media (if the information was disseminated by this media), their founders, journalists and other persons who disseminated information under their name in the media. 
However, at present, the subjects actually affected by defamation are not only natural and legal persons but also public legal entities, in particular, the Russian Federation, when defamatory information is disseminated concerning their activities.

Practical examples of defamation against the Russian Federation are numerous. These include, for example, the films shown on the German TV channel ARD, presented by journalist Hajo Seppelt about the alleged presence in Russia of the state system of doping of athletes and the involvement of the Russian Ministry of Sports in the concealment of positive doping samples of Russian athletes [3], 3] a series of articles in the U.S. press about Russia's culpability for meddling in the 2016 U.S. presidential election [4], an article in The Washington Times alleging that our state is guilty of rewriting history and starting World War II [5]. There are other examples.

These defamation cases are based on unverified, unsubstantiated information, assumptions, speculations and deliberately put Russia in a negative light, form a general negative background around the country, and discredit the state's reputation. To prevent this from happening, these situations need to be properly addressed, not only to maintain the country's position at the international level but also to strengthen its position, strengthen the country's reputation. If the Russian Federation, its reputation, is not protected from defamation, then disseminated false and untrue information will be perceived in society as truthful and true. And this can, for example, negatively affect Russia's trade and economic relations with other countries, can subsequently become the basis for sanctions against Russia, can call into question our country's contribution to the victory in World War II, will not allow our athletes to participate in international sports competitions under the state flag, etc. The result will be material and non-material damage not only to Russia in international relations and within the country but also to all entities (individuals and legal entities) under Russian jurisdiction. As quite rightly noted, "defamation unfairly interferes with another's work of self-creation and his or her ability to reap the benefits of that work, and the unjustly slandered deserve compensation to restore their own reputation so that they can compensate for the effort put into building their reputation." [6].

At the same time, Paragraph 4, Cl. 9 of the Resolution of the Plenum of the Supreme Court of the Russian Federation dated February 24, 2005, No.3 "On judicial practice in cases related to the protection of honor and dignity of citizens as well as the business reputation of legal entities" following the provisions of Articles 3-4 of the Declaration on Freedom of Political Discussion in Mass Media adopted on February 12, 2004, indicates broader limits for permissible criticism of the State and public officials to ensure the public and responsible exercise of their powers, which may allow for imaginary conclusions that any defamatory and untrue information against Russia can be disseminated with impunity, as well as the conclusion that the State has no right to protection in cases of defamation.

However, in our opinion, one should, on the one hand, distinguish between reasonable criticism of the state and its officials and, on the other hand, groundless and deliberate dissemination of defamatory information that does not correspond to reality regarding state activities. According to the common understanding, criticism is "discussion, analysis of something to make an assessment, identify shortcomings or a negative judgment about something, pointing out deficiencies" [7]. That is, criticism is an objective assessment of events and phenomena that have already taken place. Even if there is criticism that is based on a negative assessment of the state's performance, such judgement may be considered legitimate if it is objective. But when criticism is based on an assessment that is biased and deliberately denigrates the state's activity or based on unverified information that does not correspond to reality, such criticism cannot be considered acceptable. Consequently, in these situations, the editorial boards of media outlets, including editorial boards of electronic media, the editor-in-chief, and the journalist must bear responsibility for their actions for cases of defamation against the state, which are based either on statements about facts or 
events that do not occur in reality and are defamatory, or value judgments (opinions) based on these facts or events, or such value judgments are clearly biased, illogical and directly aimed at blackening the reputation of the state.

One also cannot agree with the position expressed in $\mathrm{Cl} .39$ of the Ruling of the European Court of Human Rights of October 08, 2009, No. 11751/03 in the case "Romanenko and Others vs. Russian Federation", and also in the report on the implementation of obligations and responsibilities by the Russian Federation to the Monitoring Commission of the Parliamentary Assembly of the Council of Europe, No. 10568 dated June 03, 2005, (Cl. 389, 392-393), that "the possibility of suits against mass media and journalists by public authorities should be excluded since the latter cannot in themselves possess such qualities as dignity, honor or reputation".

However, the possibility of the Russian Federation to be an equal subject of civil-law relations, both property and personal non-property, along with other participants of these relations - individuals and legal entities, and on an equal basis with these participants, is enshrined in $\mathrm{Cl}$. 1 of Article 2 of the Civil Code of the RF and in Cl. 1 of Article 124 of the Civil Code of the RF [8].

Regarding the Russian Federation's participation in property legal relations and its possession of property rights, the issue has been legally resolved. At the same time, the issues of Russia's ownership of intangible goods and personal non-property rights to them, as well as the participation of the state in personal non-property legal relations, are currently practically unexplored and not legally regulated. This is due to the widespread in doctrine special approach about belonging of intangible benefits and personal non-property rights to individuals and legal entities, and the fact that in respect of Russia, as a public-law entity, for an unknown reason, it is believed that "public-law nature overshadows its civil-law status" [9].

In this part, nowadays, the study of the participation of the Russian Federation in personal non-property relations, as an equal party to civil law relations, is very relevant, given the provision of $\mathrm{Cl} .1$ of Art. 125 of the Civil Code, which expressly recognizes the state's personal non-property rights. But what kind of personal non-property rights Russia has, one can only guess. At least, it is the right to protect business reputation $(\mathrm{Cl} .11$ of Art. 152 of the Civil Code), which is derived from the provision of Cl. 2 of Art. 124 of the Civil Code, according to which "the subjects of civil law specified in Cl. 1 of this article (the Russian Federation, the subjects of the Russian Federation: republics, territories, regions, cities of federal significance, autonomous regions, autonomous areas, as well as urban and rural settlements and other municipalities) are subject to the rules governing the participation of legal persons in relations governed by civil legislation, unless otherwise follows from the law or the characteristics of these subjects". But, there may be other rights, for example, the right to reputation in cases of defamation against Russia in the areas of its activities not directly related to business and other economic activities, not related to business reputation, but having a general social nature.

This position and the current state of affairs in the named public relations related to personal non-property rights do not allow to speak about equality in the position of the State in comparison with other participants of civil-law relations in cases of defamation, declared in Cl. 1 of Article 124 of the Civil Code of the RF. Existing legislation does not provide a meaningful opportunity to protect against defamation of the intangible good of the state, such as reputation, which has been infringed. The result of defamation is inevitably negative, material or immaterial, consequences for the state. Any civil rights, including the rights of the state as a subject of civil-law relations, may be restricted only based on federal law and only to the extent necessary for the protection of the constitutional order, morality, health, rights, and legitimate interests of others, ensuring the defense of the country and state security, which follows from Part 2 of Cl. 2 of Article 1 of the Civil Code of the RF [10]. It 
seems that the position of the European Court of Human Rights expressed in $\mathrm{Cl} .39$ of the Ruling of the European Court of Human Rights of October 08, 2009, No. 11751/03 in the case "Romanenko and Others vs. Russian Federation" as well as in the report on the fulfillment of obligations and responsibilities by the Russian Federation to the Monitoring Commission of the Parliamentary Assembly of the Council of Europe No. 10568 dated June 03, 2005, (Cl. 389, 392-393) does not meet the objectives indicated in this Article of the Civil Code.

In addition, it should be noted that the possibility of non-application of the position expressed by the European Court of Human Rights and the Monitoring Commission of the Parliamentary Assembly of the Council of Europe can be justified by Cl. 2.2 of the Decision of the Constitutional Court of the Russian Federation of July 14, 2015, No. 21-P "On the case of checking the constitutionality of the provisions of Article 1 of the Federal Law "On ratification of the Convention for the Protection of Human Rights and Fundamental Freedoms and its Protocols", Cl. 1 and 2 of Article 32 of the Federal Law "On International Treaties of the Russian Federation", parts one and four of Article 11, Cl. 4 of part four of Article 392 of the Civil Procedural Code of the Russian Federation, parts 1 and 4 of Article 13, Cl. 4 of part 3 of Article 311 of the Arbitration Procedural Code of the Russian Federation, parts 1 and 4 of Article 15, Cl. 4 of part 1 of article 350 of the Administrative Procedural Code of the Russian Federation and Cl. 2 of part 4 of Article 413 of the Criminal Procedural Code of the Russian Federation in connection with the request of a group of deputies of the State Duma", according to which "... neither the Convention for the Protection of Human Rights and Fundamental Freedoms as an international treaty of the Russian Federation, nor legal positions of the European Court of Human Rights based on it, containing assessments of national legislation or concerning the need to change its provisions, cancel for the Russian legal system the priority of the Russian Federation Constitution and therefore are subject to implementation within this system only subject to recognition of the highest legal force exactly the Russian Constitution... Based on this, in a situation where the very content of the judgment of the European Court of Human Rights, including in the part of the orders addressed to the respondent state, based on the provisions of the Convention for the Protection of Human Rights and Fundamental Freedoms, interpreted by the European Court of Human Rights within the framework of specific cases, illegally - from a constitutional and legal point of view - the principles and norms of the Constitution of the Russian Federation are affected, Russia may, as an exception, deviate from fulfilling the obligations imposed on it, when such a deviation is the only possible way to avoid violation of the fundamental principles and norms of the Constitution of the Russian Federation"ю

It is also worth mentioning the case law in Italy where the Italian Supreme Court has stated that "defamation may damage the image and prestige of the State, which therefore suffers moral damage that cannot be precisely measured in money terms based on market criteria, manifested in violation of non-property rights (cassation judgment of 5 December 1992 in case No. 12951) [11].

Based on the foregoing, it appears that in order to prevent Russia from suffering the negative consequences that may result from frequent cases of defamation, it is necessary to ensure that Russia's reputation is legally protected against defamation under civil law.

This requires, first and foremost, a legislative definition of the term 'defamation'. The definition of defamation as "similar to the dissemination of defamatory information not corresponding to reality contained in Article 152 of the Civil Code of the Russian Federation" specified in Cl. 1 of the Resolution of the Plenum of the Supreme Court No. 3 dated February 24,2005 , "On judicial practice in cases concerning protection of honor and dignity of citizens as well as the business reputation of legal entities" is narrow and does not reflect all specific features of this phenomenon, which can protect the offended party. In addition, we cannot 
agree that the concept of "defamation" is identified with a specific rule of law (the rule of Art. 152 of the Civil Code) since the existence of identity implies complete overlap.

The use of the term 'defamation' in Russian law and its normative enshrining in this particular meaning is certainly required, based on the wide use of this generally accepted legal term in most foreign countries and in international law, such as in the rulings of the European Court of Human Rights. Thus, if protection of moral rights is to be sought in cases of the dissemination of untrue, defamatory information, for example, in relations with a foreign element or outside the territory of our country, the term 'defamation' should be defined in law to ensure that it is commonly understood by non-residents, such as 'defamation', so that it can be protected most effectively and so that it is easier to do so.

The need to enshrine the term 'defamation' in the law has also been highlighted internationally. For example, in 2007, the Council of Europe Assembly adopted a special resolution calling on "member states to define defamation more precisely in their legislation to avoid arbitrary application of the law and to provide effective civil law protection of the human dignity of persons affected by defamation" [12].

Secondly, it is necessary to legally define that Russia, as an independent participant of civil-law relations, can be a subject affected by defamation, along with citizens and legal entities. Failure to do so will result in the constant questioning, at all levels (legislative, doctrinal, law enforcement), of whether the state has the right and the ability to protect itself in cases of defamation, which should in no way be allowed at this time when defamation against our country is in fact rampant.

Thirdly, it is necessary to normatively define such intangible good as reputation, which may be possessed by such a subject of civil-law relations as Russia, which may suffer from defamatory encroachment in respect of it. If the defamation relates to the business sphere, the economic sphere, then, obviously, we should talk about the protection of "business reputation". If the violation relates to any other sphere, the affected intangible good will be the "reputation" of Russia, which relates to a broader sphere of social relations, which includes a general social assessment of the state activity, and not only the assessment of business and other economic activities.

The concept of "reputation", along with "defamation", is also a common term in Western legal systems when it comes to identifying an intangible good affected by defamation. And, in this regard, the use of the concept of "reputation" will also contribute to the purpose of protecting against defamation of personal non-property rights of the Russian Federation.

\section{Conclusion}

The scientific novelty of the research consists in the fact that based on available knowledge in the field of civil law, knowledge of international law, the provisions of judicial practice, legal doctrine, the need for a legislative definition of such concept as "reputation" - a separate type of intangible assets, which actually has Russia, as a subject of civil law, the need for a legislative definition of such concept as "defamation" - a special type of civil violation, as well as fixing as an equal subject - the Russian Federation, which, along with individuals and legal entities, can also be a victim of defamation.

It has become impossible to imagine today's world without media, without communication, without the Internet. You have to live on at least a desert island or in the middle of nowhere to have no access to news from the outside world. The media have existed for a long time, but they have achieved the greatest influence on the surrounding reality nowadays, in the era of the digital economy, "all-pervasive" Internet; therefore, they are rightfully called the fourth power.

Many phenomena of modern reality, the perceptions of which are available in society, receive an interpretation that is fundamentally different from the original one with the lapse 
of time. A huge role in this is played by the media, which, thanks to advances in the digital sphere, literally shapes people's consciousness and their way of thinking [13]. In this part, the information sphere of public and state life becomes open and vulnerable to all kinds of fake news and publications, which to a large extent makes it an environment "favorable" for abuses and the commission of offenses.

In cases of defamation against the Russian Federation, it is important to respond quickly and effectively, to protect the personal non-property rights of the state, for which a range of measures, including legal measures, must be taken. If this is not done, the position of our country, with a large flow of defamatory and untrue information, will be destabilized, and its reputation in the eyes of the world community will be lowered. In turn, this will form a negative attitude towards Russian citizens and organizations, as there is an obvious mutual influence of the reputation of the state with the reputation of citizens and organizations [14]. Russian citizens will be ashamed of being Russian, and Russian companies will suffer losses due to the unwillingness of foreign companies to cooperate with them in trade and economic spheres because of their connection to the Russian jurisdiction. In this regard, there is certainly a need to introduce the terms "defamation" and "reputation" into civil law and define them accordingly and formalize the fact that the Russian Federation can be a subject affected by defamation along with individuals and legal entities.

\section{References}

1. A. Aba-Catoira, Revista de Derecho Político 1(109), 119 (2020)

2. G.F. Shershenevich, Textbook of Russian Civil Law, 7 (1995)

3. Kommersant: The German TV channel showed a new film about doping in Russian sport ARD talks about the pressure of the Ministry of Sports of the Russian Federation on WADA: https://www.kommersant.ru/doc/3008365

4. https: //www.theguardian.com/us-news/2016/dec/10/cia-concludes-russia-interfered-tohelp-trump-win-election-report; https://edition.cnn.com/2016/12/02/politics/russiafake-news-reality/; https://warontherocks.com/2016/11/trolling-for-trump-how-russiais-trying-to-destroy-our-democracy/

5. The Washington times: Kremlin rewriting World War II history: https://www.washingtontimes.com/news/2019/aug/13/whitewashing-culpability/

6. L. Lidsky, C. Robert, The Social Foundations of Defamation Law: Reputation and the Constitution, Communication Law and Policy 25(4), 491 (2020)

7. S.I. Ozhegov, Dictionary of the Russian Language, 271 (1983)

8. E.E. Frolova, T.A. Polyakova, M.N. Dudin, E.P. Rusakova, P.A. Kucherenko, J. of Advanced Research in Law and Economics 9(1), 89 (2018)

9. V.S. Tolstoy, Personal non-property legal relations, 202 (2009)

10. M.N. Dudin, O.F. Shakhov, M.S. Shakhova, E.P. Rusakova, Y.S. Sizova, Int. J. of Recent Technology and Engineering 8(2), 4436 (2019)

11. E. Gavrilov, Economy and Law 3, 98 (2012)

12. Assembly Debate on 04 October 2007 (34th Sitting) (see Doc. 11305, Report of the Commission on Legal Affairs and Human Rights, rapporteur Mr Bartumsu-Kassani)

13. E.P. Rusakova, E.E. Frolova, A.I. Gorbacheva, Advances in Intelligent Systems and Computing 1100, 665 (2020)

14. M.N. Kuznetsov, Bulletin of the Moscow State Regional University 4, 162 (2020) 